combat. I had him, and he had me. My left index finger was deep in his chest, and his right fist clutched my ability to sire future generations. It was Capulet and Montague, St. George and the Dragon, Ralph Klein and the Canada Health Act. All this flashed by in the instant that it took my own pain impulses to traverse the pudendal nerves and reach my brain.

I screamed. "You trucker!" (or words to that effect). Then I rammed the tube toward his cerebellum, by way of the right pleural space. Fortunately (from a medicolegal standpoint), it stopped conveniently at the lung apex and did not doom him to the life of slurred speech and ataxia that I intended.

This stunning assault on his pleural space caused him to release my nightlife. I disengaged and sewed him up in a flash, all the while resisting the desperate urge to drop everything and rush to the loo to inspect the damage. When I finally slunk out, I bumped into the SSR (grinning like an idiot) and one of the attendings, who'd seen the whole thing - or thought he had.

"Well, Huber," he chuckled, "you finally did it. That was the fastest chest tube I've ever seen. You really had balls to ace it when he was yelling at you. Next time, go a little easier on the insertion though."
I grinned weakly, confidence in my "balls" somewhat shaken.

Later, back in the trauma room, one of the nurses approached, jabbed the trauma flow-sheet at me and said, "Dr. Huber, would you mind putting your John Henry on this?"

She probably never understood why I panicked and ran. You see, in New Zealand, "John Henry" refers not to a man's signature, but to his ...

Since then, I've done many chest tubes, but none as slick as that first one.

Or as dangerous.

Correspondence to: Dr. Alan Huber; alan_huber @bc.sympatico.ca

\title{
I Am a Canadian Doctor
}

\section{(A tribute to Canadian medicine inspired by the "I Am Canadian" commercials)}

I'm not wealthy, or golfing on Wednesdays. I don't enjoy health politics, and I don't know Dr. Doug Ross, Dr. John Carter or Dr. Kerry Weaver from ER, but I'm sure they all make much more money than I do.

I enjoy helping the sick and I speak medical lingo sometimes without realizing it. I enjoy medical trivia,

using Greek and Latin words when I could easily use layman's terms, and rereading The House of God.

I believe in universal health care, but realize that it cannot continue in the current medical paradigm.

In medicine, the patient comes first.

I can speak authoritatively on countless medical conditions, yet I can't recall the basic sciences. And maybe I can't read my own handwriting, but at least I know what I mean to have written.

Because Canadian medicine is still the best medical system in the world.

The home of Banting \& Best, Norman Bethune, and William Osler.

The profession where despite frustrations in health politics and underfunding, medicine is still practised at a world-class level.

My name is Doctor and I am Canadian. I toast to your health!

- Benjamin Barankin

3rd year medical student, University of Western Ontario,

London, Ont.

Correspondence to: bbarankin@julian.uwo.ca 